\title{
BASIC ANATOMICAL AND PHARMACOGNOSTICAL STUDY OF CASSIA FISTULA LINN (CAESALPINIACEAE)
}

\section{B.Lavanya*, N.Narayanan, A.Maheshwaran, S.Suganya, Y.Surya sree, S.Vel Aravindan and M.Vigneshwar}

Jaya College of Paramedical Science, College of Pharmacy, Thiruninravur, Chennai, Tamilnadu, India.

*Corresponding Author Email: blavanyavels@gmail.com

\section{ABSTRACT}

Aim: To perform the basic anatomy and pharmacognostical study of the plant cassia fistula Linn. Materials and Methods: The cassia fistula was collected, authentified and performed the review of the plant, physicochemical, microscopical, Powder microscopical and Pharmacognostical evaluations. Conclusion: Standardisation of the plant using the basic anatomical study such as microscopical and powder microscopical study and physiochemical studies for further proceedings in future.

\section{KEY WORDS}

Cassia fistula, Pharmacognostical evaluation physical evaluation, chemical evaluation.

\section{AIM OF WORK}

Introduce the plant by using Ethanobotanical study, Microscopical study and physicochemical evaluation.

\section{PLAN OF THE WORK:}

- Introduction about plant and authentification.

- Ethanobotanical review

- Secondary and tertiary metabolites study

- Folkclore study of drug for future studies

- Microscopical studies

- Powder microscopy

- Physicochemical evaluation

\section{I.INTRODUCTION}

Cassia fistula Linn. (Cassia) family Caesalpiniaceae known as Amulthus/indian laburnum ${ }^{1}$. It is one of the drugs present in tropical regions of Asia. Cassia is naturally distributed across India. The various parts of the tree like the bark, root, flowers, leaves, fruit pulp are used medicinally and have several health benefits. It has been extensively used in Ayurvedic system of medicine for various ailments ${ }^{2}$. By studying the ethano botanical review, secondary and tertiary metabolites, folkclore literature shows that, the drug which exhibit more than 25 pharmacological uses.

II. GEOGRAPHICAL DISTRIBUTION

Cassia fistula was available in deciduous forests throughout the greater parts of India, ascending to $1300 \mathrm{~m}$ in outer Himalaya ${ }^{3}$. In Maharashtra, it scattered as a tree throughout the Deccan and Konkan. The plant is cultivated as an ornamental throughout India. 


\section{ETHANO BOTANICAL REVIEW:}

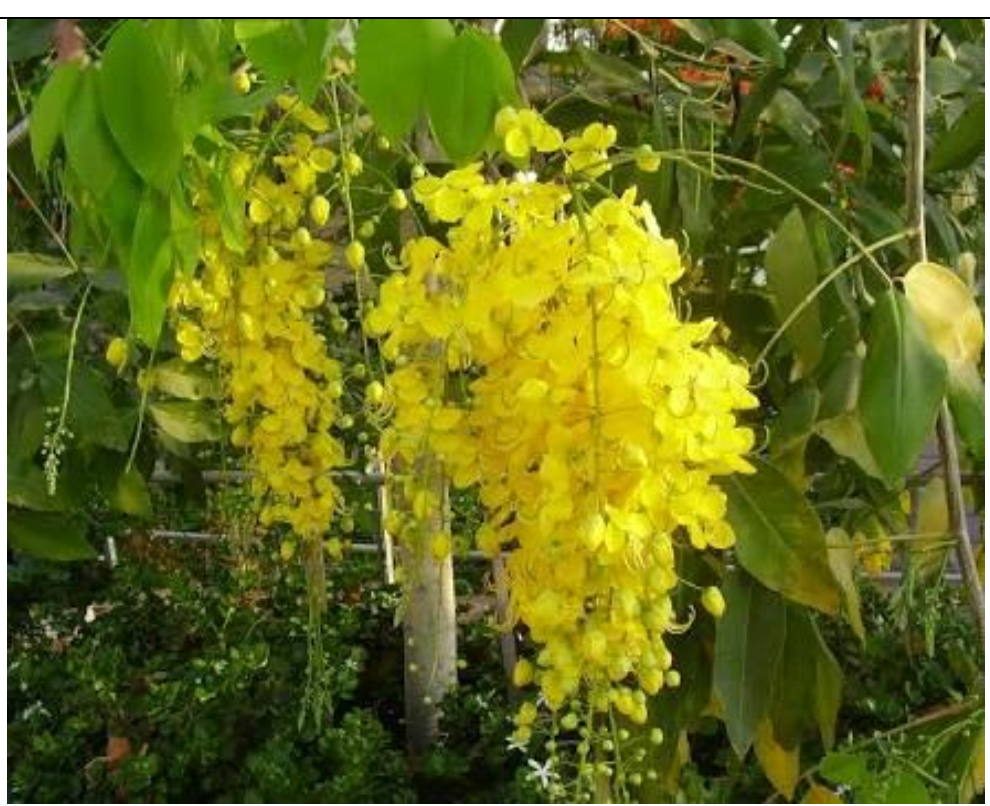

- Flowers deep yellow in terminal, drooping ${ }^{4}$ racemose.

- 30-60 cm in length.

- Calyx is usually oblong, obtuse and pubescent.

- Corolla with 5 subequal, obovate, small clawed petals.

- Stamens present 10 in numbers, axial present 3 in numbers with erect filaments with basal fixed curved anthers ${ }^{5}$.
- Cassia fistula is a medium sized tropical deciduous tree, $10 \mathrm{~m}$ tall with a straight trunk to $5 \mathrm{~m}, 1 \mathrm{~m}$ diameter and spreading branches.

- Stem is grey, smooth and slender when young and dark brown and rough when old.

- Leaves are alternate, usually pinnate, $30-40 \mathrm{~cm}$ in length, with $4-8$ sets of ovate leaflets, $7.5-15 \mathrm{~cm}$ in length, 2-5 cm thick, entire, and the petioles 2-6 $\mathrm{mm}$ in length ${ }^{5}$.

\begin{tabular}{lll}
\hline IV. CLASSIFICATION & & \\
\hline & Kingdom: & Plantae \\
& Subkingdom: & Tracheobinota \\
Super Division: & Spermatophyta \\
Division: & Mangoliophyta \\
Class: & Magnoliopsida \\
Sub Class: & Rosidae \\
Order: & Fabales \\
& Family: & Fabacae \\
& Genus: & Cassia \\
& Species: & Fistula \\
\hline
\end{tabular}




\section{V.VERNACULAR NAMES ${ }^{5}$}

\begin{tabular}{ll}
\hline Bengali & Amultash, sondal, sonali \\
English & Golden shower, Indian laburnum \\
Gujarati & Girmala \\
Hindi & Bandarlathi, bharva, suvarnaka \\
Malayalam & Tengguli, rajah \\
Sanskrit & Saraphala, survanaka, argwadha, rajtaru \\
Tamil & kavani, konnai, tirukontai, sarakkonne, Raelachettu \\
Telugu & Kakkemara \\
Marathi & Bahava \\
Punjabi & Amaltaas, Kaniyaar, Girdnalee \\
Oriya & Sunaari \\
Urdu & Amaltaas \\
Arab & Khayarsambhar, chaiyaphruek, khuun \\
Thai & Canâfistula mansa,chácara, GuayabaCimarrona \\
Spanish & Bâton casse, casse doux, casse espagnol \\
Trade name & Indian laburnum \\
\hline
\end{tabular}

\section{VI.COLLECTION AND AUTHENTIFICATION}

The barks of cassia fistula were collected from Ariyalur district, Tamil Nadu and it was Taxonomic identified and authenticated by Prof. Dr.P. Jayaraman, Ph.D, Director, Retd, Plant Anatomy Research Centre (PARC) West Tambaram, Chennai. An authentification certificate number PARC/2015/3025. The bark of cassia fistula was separated and shade dried. The dried material was reduced to a coarse powder and was successively extracted in soxhlet apparatus using ethyl acetate for $24 \mathrm{hrs})$. The solvents were redistilled and ethyl acetate extract was concentrated under reduced pressure and air dried. The yield of ethyl acetate extract was found to be $36 \% \mathrm{w} / \mathrm{w}$.

\section{VII.LITERATURE REVIEW}

VII. i) BRIEF DESCRIPTION OF THE SECONDARY AND TERTIARY METABOLITES PRESENT IN THE VARIOUS PARTS OF CASSIA FISTULA

\begin{tabular}{lll}
\hline Bark & $\bullet$ & $\begin{array}{l}\text { Flavonol glycosides } \\
\text { Oxyanthraquinone } \\
\end{array}$ \\
& $\bullet$ & Dihydroxyanthraquinone \\
\hline Pods & $\bullet$ & Arabinopyranoside \\
& - & 5-Nonatetracontanone \\
& 2-Hentriacontanone
\end{tabular}




\begin{tabular}{|c|c|c|}
\hline Leaves & $\begin{array}{l}\bullet \\
\bullet \\
\bullet \\
\bullet \\
\bullet \\
\bullet \\
\bullet \\
\bullet \\
\bullet \\
\bullet \\
\bullet\end{array}$ & $\begin{array}{l}\text { Quinone glycosides } \\
\text { Sennosides A } \\
\text { Glucoside } \\
\text { Barbaloin } \\
\text { Aloin } \\
\text { Formic acid } \\
\text { Butyric acid } \\
\text { Oxalic acid } \\
\text { Pectin } \\
\text { Tannin }\end{array}$ \\
\hline Flowers & $\begin{array}{l}\text { - } \\
\bullet \\
\bullet \\
\bullet \\
\bullet \\
\bullet \\
\bullet \\
\bullet \\
\bullet \\
\bullet \\
-\end{array}$ & $\begin{array}{l}\text { Anthraquinone glycosides } \\
\text { Hentriacontanoic acid } \\
\text { Triacontanoic acid } \\
\text { Nonacosanoic acid } \\
\text { Heptacosanoic acids } \\
\text { Ceryl alcohol } \\
\text { Kaempferol } \\
\text { Anthraquinone glycoside } \\
\text { Fistulin } \\
\text { Aurantiamide acetate } \\
\text { B -sitosterol } \\
\text { B-D glucoside } \\
\text { Triterpenes }\end{array}$ \\
\hline Fruit & $\begin{array}{l}\bullet \\
\bullet \\
\bullet \\
\bullet \\
\bullet \\
\bullet \\
\bullet \\
\bullet \\
\bullet \\
\end{array}$ & $\begin{array}{l}\text { Ceryl alcohol } \\
\text { Kaempferol } \\
\text { Rhein } \\
\text { Bianthraquinone glycoside } \\
\text { Fistulin } \\
\text { Rhein, } \\
\text { Sennosides A \& B } \\
\text { Anthraquinone } \\
\text { Tannins } \\
\text { Oxyanthraquinone } \\
\end{array}$ \\
\hline Pulp of the pod & $\begin{array}{l}\bullet \\
\bullet \\
\bullet \\
\bullet \\
\bullet \\
\bullet\end{array}$ & $\begin{array}{l}\text { Anthraquinone glycosides } \\
\text { Sennosides } A \& B \\
\text { Rhein and its glucoside, } \\
\text { Barbaloin } \\
\text { Formic acid } \\
\text { Oxalic acid }\end{array}$ \\
\hline Pulp & $\begin{array}{l}\bullet \\
\bullet \\
\bullet \\
\bullet \\
\bullet \\
\bullet \\
\bullet \\
- \\
- \\
-\end{array}$ & $\begin{array}{l}\text { Sugar moiety } \\
\text { Tannic substance } \\
\text { Albuminous starch } \\
\text { Calcium oxalate } \\
\text { Gluten } \\
\text { Sucrose, } 31.3 \% \\
\text { Fructose, } 26.2 \\
\text { Glucose, } 42.5 \% \\
\text { High concentration of potassium } \\
\text { Gum } \\
\text { Gluten }\end{array}$ \\
\hline Root & • & $\begin{array}{l}\text { 7-Methylphyscion } \\
\text { Betulinic acid }\end{array}$ \\
\hline
\end{tabular}




\begin{tabular}{|c|c|}
\hline & B-sitosterol \\
\hline Root bark & $\begin{array}{ll}- & \text { Tannins } \\
\text { - } & \text { Phlobaphenes and } \\
\text { - } & \text { Oxyanthraquinone } \\
\end{array}$ \\
\hline Seed oil & $\begin{array}{ll}\text { - } & \text { Cyclopropenoid fatty acids } \\
\text { - } & \text { Vernolicid } \\
\text { - } & \text { Malvalic acid } \\
\text { - } & \text { Stetculic acid }\end{array}$ \\
\hline Fruit pulp & $\begin{array}{ll}\text { - } & \text { Cyclopropenoid fatty acids } \\
\text { - } & \text { Vernolic acid } \\
\text { - } & \text { Malvalic acid } \\
\text { - } & \text { Stetculic acid } \\
\end{array}$ \\
\hline Powdered stem bark & $\begin{array}{ll}- & \text { Tannins } \\
- & \text { Lupeol } \\
- & \text { Haxacosanol } \\
- & \text { B-sitosterol } \\
\end{array}$ \\
\hline Seed & $\begin{array}{ll}\text { - } & \text { Sterculic acid } \\
\text { - } & \text { Malvalic acid } \\
\text { - } & \text { Glycerides } \\
\text { - } & \text { Oleic acid } \\
\text { - } & \text { Linoleic acid } \\
\text { - } & \text { Stearic acid } \\
\text { - } & \text { Palmitic acid } \\
\text { - } & \text { Cephalin } \\
\text { - } & \text { Lecithin } \\
\text { - } & \text { Phospholipids and } \\
\text { - } & \text { Carbohydrates (11.8\%). }\end{array}$ \\
\hline Flower's pollen & $\begin{array}{ll}- & \text { Amino acids } \\
& \text { Carbohydrate (11.75) }\end{array}$ \\
\hline Wood & $\begin{array}{l}\text { - Fistucacidin } \\
\left(3,4,7,8,4^{\prime} \text {-pentahydroxyflavan). }\right.\end{array}$ \\
\hline Vegetative organs & $\begin{array}{ll} & \text { Proanthocyanidins, } \\
\text { - } & \text { Flavonoids } \\
\end{array}$ \\
\hline Entire plant & $\begin{array}{ll}\text { - } & \text { Tannin } \\
\text { - } & \text { Saccharose 53-66\%; } \\
\text { - } & \text { Invert sugar } \\
\text { - } & \text { Citric acid } \\
\text { - } & \text { Coloring matter } \\
\text { - } & \text { Pectin } \\
\text { - } & \text { Anthraquinone }\end{array}$ \\
\hline Flower oil & $\begin{array}{ll}- & \text { (E)-Nerolidol (38\%) } \\
\text { - } & \text { 2-Hexadecanone (17\%), }\end{array}$ \\
\hline Leaf oil & Phytol (16.1\%). \\
\hline
\end{tabular}




\section{III .ii) BRIEF STUDY OF THE CASSIA FISTULA PARTS}

\begin{tabular}{|c|c|c|c|}
\hline S.NO & PART OF THE PLANT & USES & \\
\hline 1. & Seed & $\begin{array}{l}\bullet \\
\bullet \\
\text { - } \\
\text { - } \\
\text { - } \\
\text { - } \\
\text { - } \\
\text { - }\end{array}$ & $\begin{array}{l}\text { Skin diseases } \\
\text { Abdominal discomfort } \\
\text { Leprosy } \\
\text { Laxative } \\
\text { Carminative } \\
\text { Cooling agent } \\
\text { Anti-pyretic properties } \\
\text { Constipation }\end{array}$ \\
\hline 2. & Flower & $\begin{array}{l}\cdot \\
\cdot \\
\text { - } \\
\text { - } \\
\text { - } \\
\text { - } \\
\text { - } \\
\text { - }\end{array}$ & $\begin{array}{l}\text { Skin diseases } \\
\text { GIT disorder } \\
\text { Leprosy } \\
\text { Astringent } \\
\text { Laxative } \\
\text { Febrifugal } \\
\text { Wound healing properties } \\
\text { Decoction of the flowers is given for stomach troubles }\end{array}$ \\
\hline 3. & Fruit & $\begin{array}{l} \\
\bullet \\
\bullet\end{array}$ & $\begin{array}{l}\text { Skin diseases } \\
\text { Fever } \\
\text { Abdominal pain leprosy }\end{array}$ \\
\hline 4. & Root & $\begin{array}{l}\bullet \\
\bullet \\
\bullet \\
\bullet \\
\bullet \\
\bullet\end{array}$ & $\begin{array}{l}\text { Cardiac disorders } \\
\text { Biliousness } \\
\text { Rheumatic condition } \\
\text { Hemorrhages } \\
\text { Wounds boils } \\
\text { Ulcers }\end{array}$ \\
\hline 5. & Pulp & 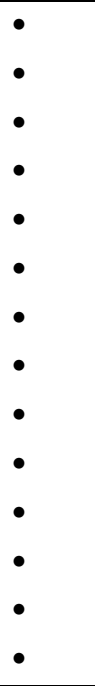 & $\begin{array}{l}\text { Purgative } \\
\text { Disorders of liver } \\
\text { Biliousness } \\
\text { Tonic } \\
\text { Gout } \\
\text { Rheumatic condition. } \\
\text { Antipyretic } \\
\text { Remedy for malaria } \\
\text { Blood-poisoning } \\
\text { Anthrax } \\
\text { Diahorrea } \\
\text { Leprosy } \\
\text { Diabetes } \\
\text { Removal of abdominal obstructions }\end{array}$ \\
\hline 6. & Leaves & $\bullet$ & laxative \\
\hline 7. & Ripe pod & $\begin{array}{l}\cdot \\
\bullet \\
\bullet\end{array}$ & $\begin{array}{l}\text { traditional medicines } \\
\text { laxative drug } \\
\text { Anthelmintic Activity }\end{array}$ \\
\hline
\end{tabular}




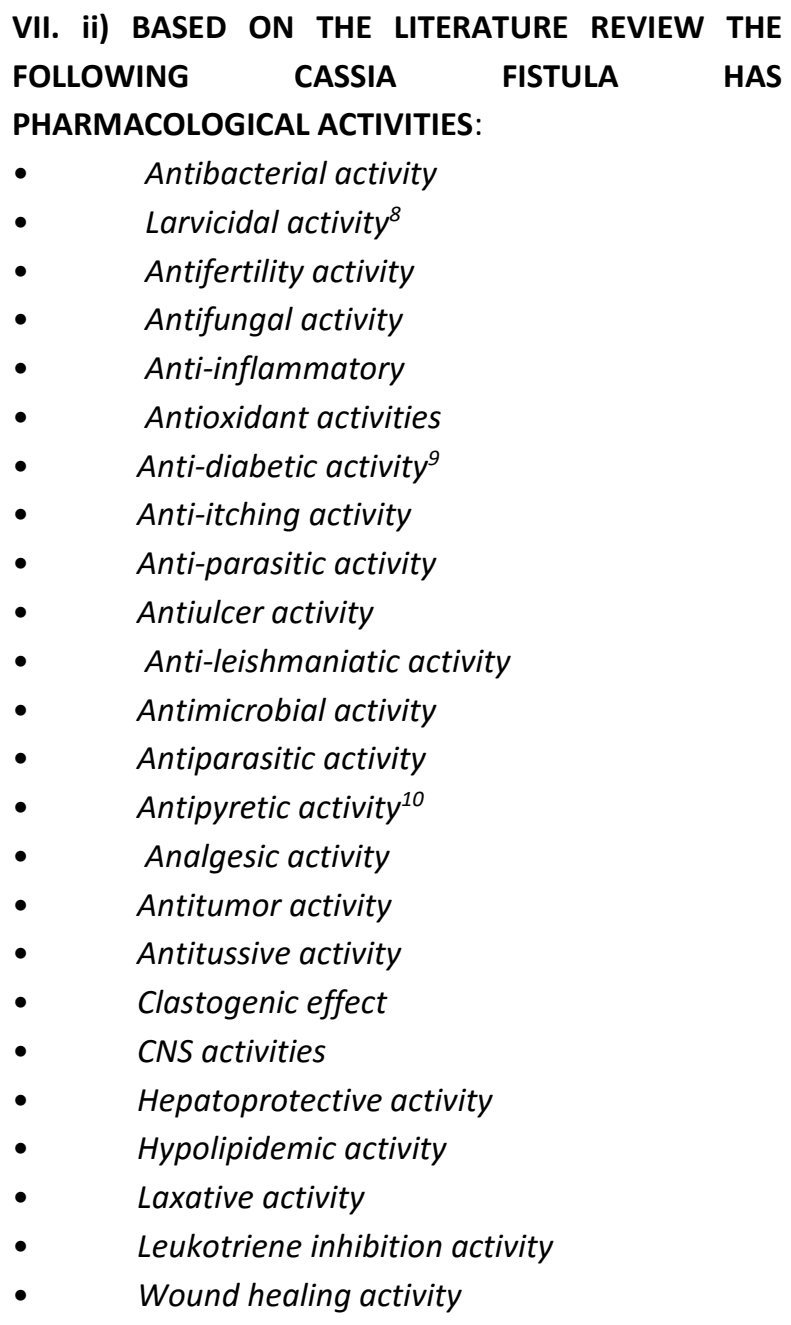

\section{VIII.PHARMACOGNOSTICAL EVALUATION:}

The curde drug is studied phrmacogntically and its microscopical studies as follows

VIII. i) morphological study

- Colour: Deep brown

- Odour: characteristic agreeable

- Taste: Bitter

- Size :20-40 cm

\section{VIII.ii) MICROSCOPICAL STUDY}

The microscopical studies ${ }^{11}$ are performed using the standard procedure and results are given below

\section{VIII.iii) POWDER MICROSCOPY}

The powder preparation of the bark tissue shows the following inclusions.

FIBRE:

There are long, thick walled fibre with narrow tapering ends
The lumen of the fibre is narrow and the cell walls are lignified.

The fibres are up to $1.3 \mathrm{~mm}$ in length and $50 \mu \mathrm{m}$ in thickness.

\section{SCLEREIDS:}

Scattered in the powder are small, squarish highly thick walled sclereids which are called brachy sclereids ${ }^{7}$.

The sclereids are $10 \mu \mathrm{m}$ in length and breath

\section{PHLOEM PARENCHYMA CELLS:}

The vertical row of rectangular parenchyma cells is seen in thick bundles.

Within the parenchyma cells are seen cuboidal calcium oxalate crystals.

The crystals are in single vertical row within each parenchyma strand.

VIII.iv) PHYSICOCHEMICAL EVALUATION ${ }^{12}$ :

a. The physical evaluations are performed for the crude drug of cassia fistula linn.

Moisture content

Moisture content were determined by heating the crude drug at $105^{\circ} \mathrm{c}$ in an oven to a constant weight by this we can determine the active chemical constituents of the drug on air dry bases.

\section{Ash content}

Total ash value

The sample of crude drug were admixed with sand, soil, calcium oxalate, chalk powder then it is made to incinerate, then the inorganic salt content was determined.

\section{Acid insoluble ash}

A part of total ash was dissolved in dil.Hcl, filtered and then weight of the residue was measured.

\section{Extractive value}

Water soluble extractive

The drug is exhausted with water and extract were obtained

\section{Alcohol soluble extractive}

Alcohol being the ideal solvent for extraction, the drug is exhausted with alcohol and extractive value was found.

\section{Ether soluble extractive}

The drug is exhausted with non-volatile ether so that extractive value of drugs could be obtained

b.The chemical evaluations are performed for the crude drug of cassia fistula linn. 
The chemical test for the crude drug is performed and the results are tabulated below.

\section{IX.RESULT AND DISCUSSION}

IX. i) Result of microscopical studies ${ }^{14}$

Figure 1.1: Surface view of the bark showing thick flakes

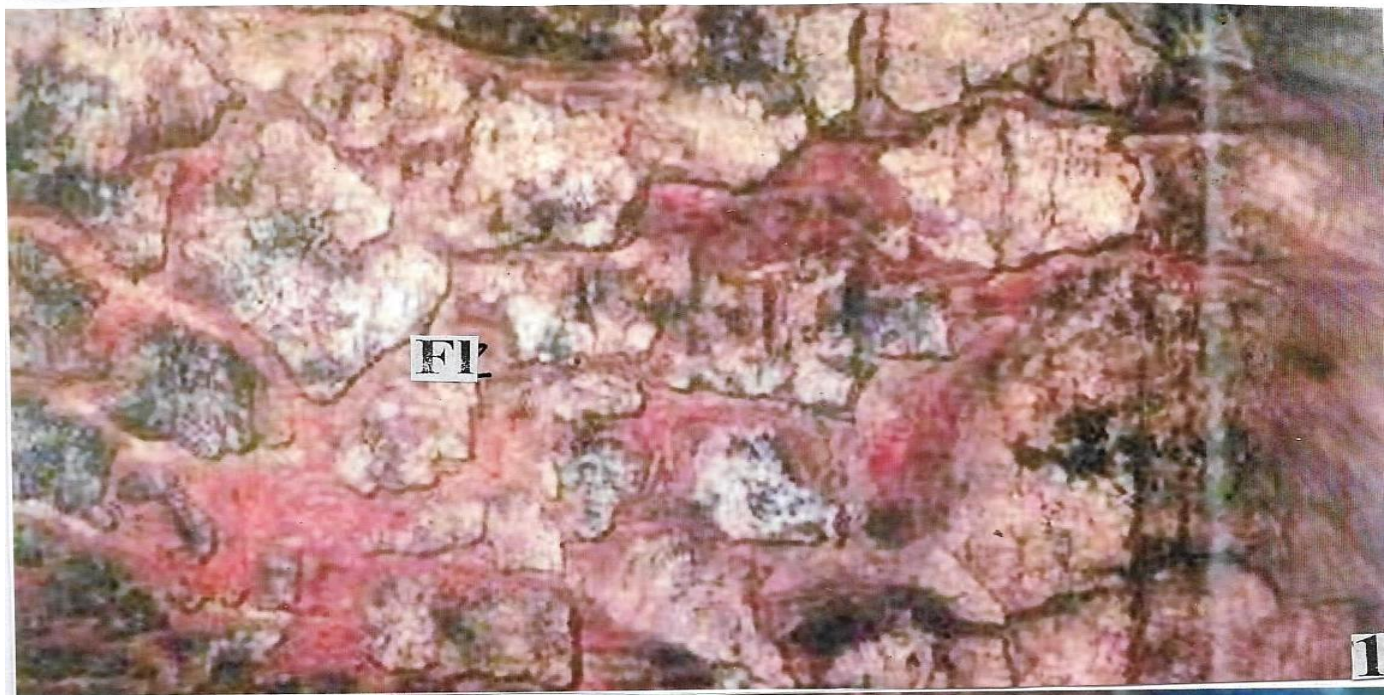

Figure 1.2: Bark cut transverly showing outer bark (periderm) and inner secondary phloem of scollapsed and noncollapsed phloem zones.

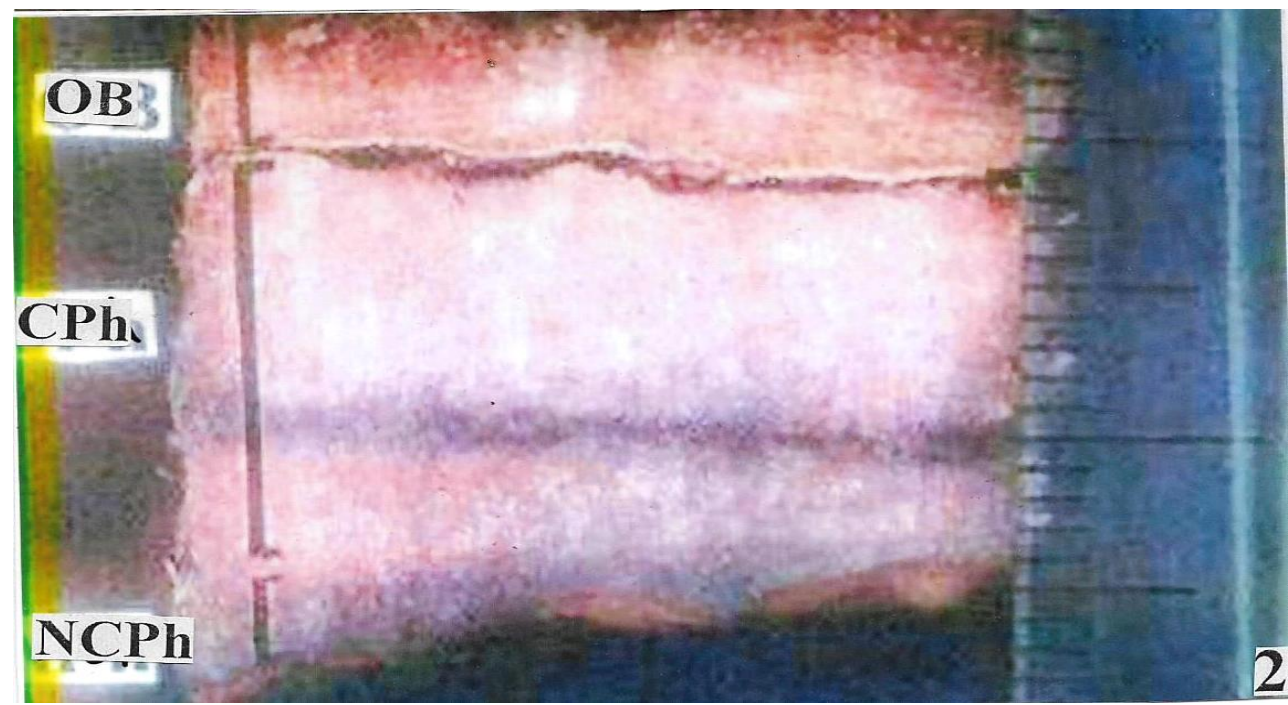

(cph - collapsed phloem; ob- Outer bark ; Ncph - Non-collapsed phloem ;)

Figure 2.1: T.s of collapsed phloem zone showing thick dark tangential lines. 


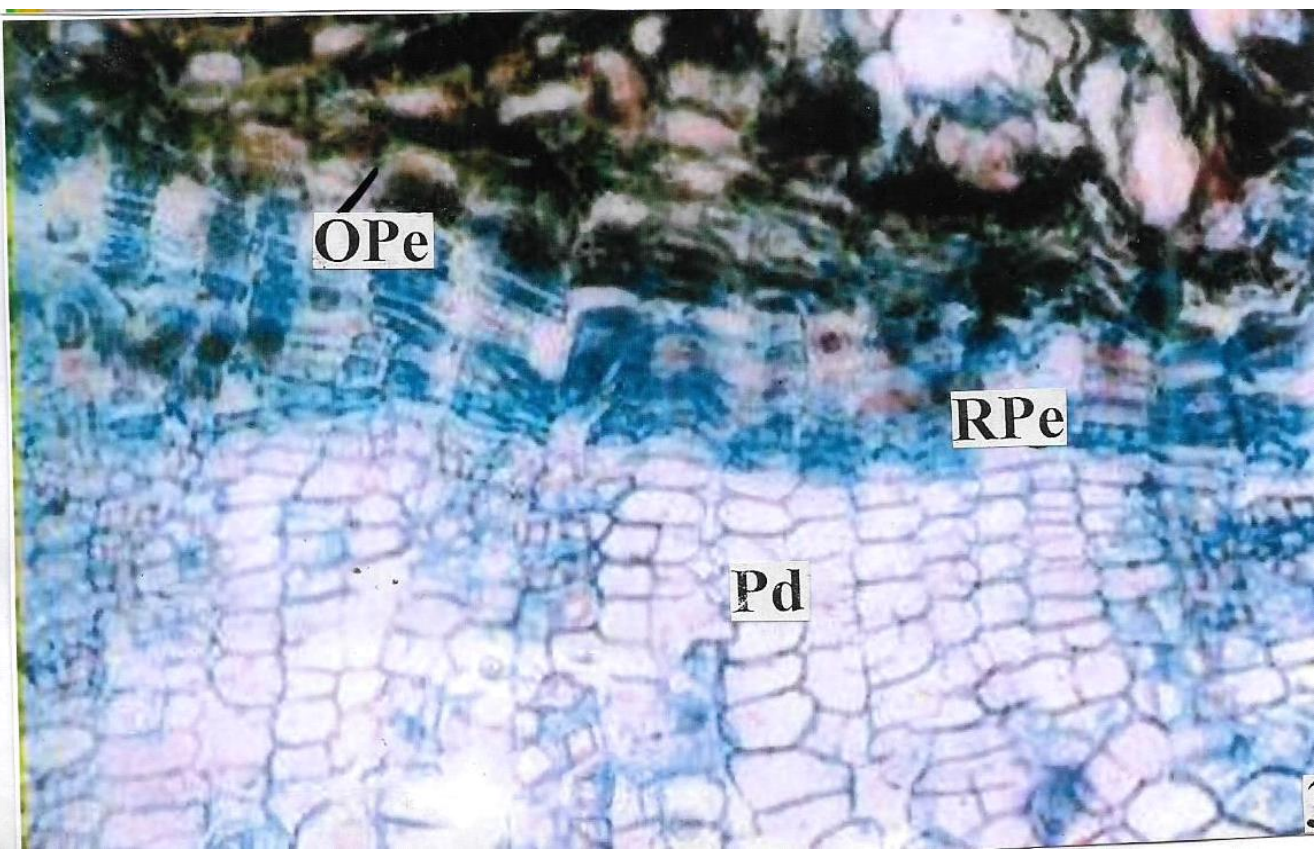

(cph-collapsed phloem; PhR - phloem ray; PhF-phloem fibre)

Figure 2.2: T.s of collapsed phloem showing tangential dark lines of crushed phloem elements.

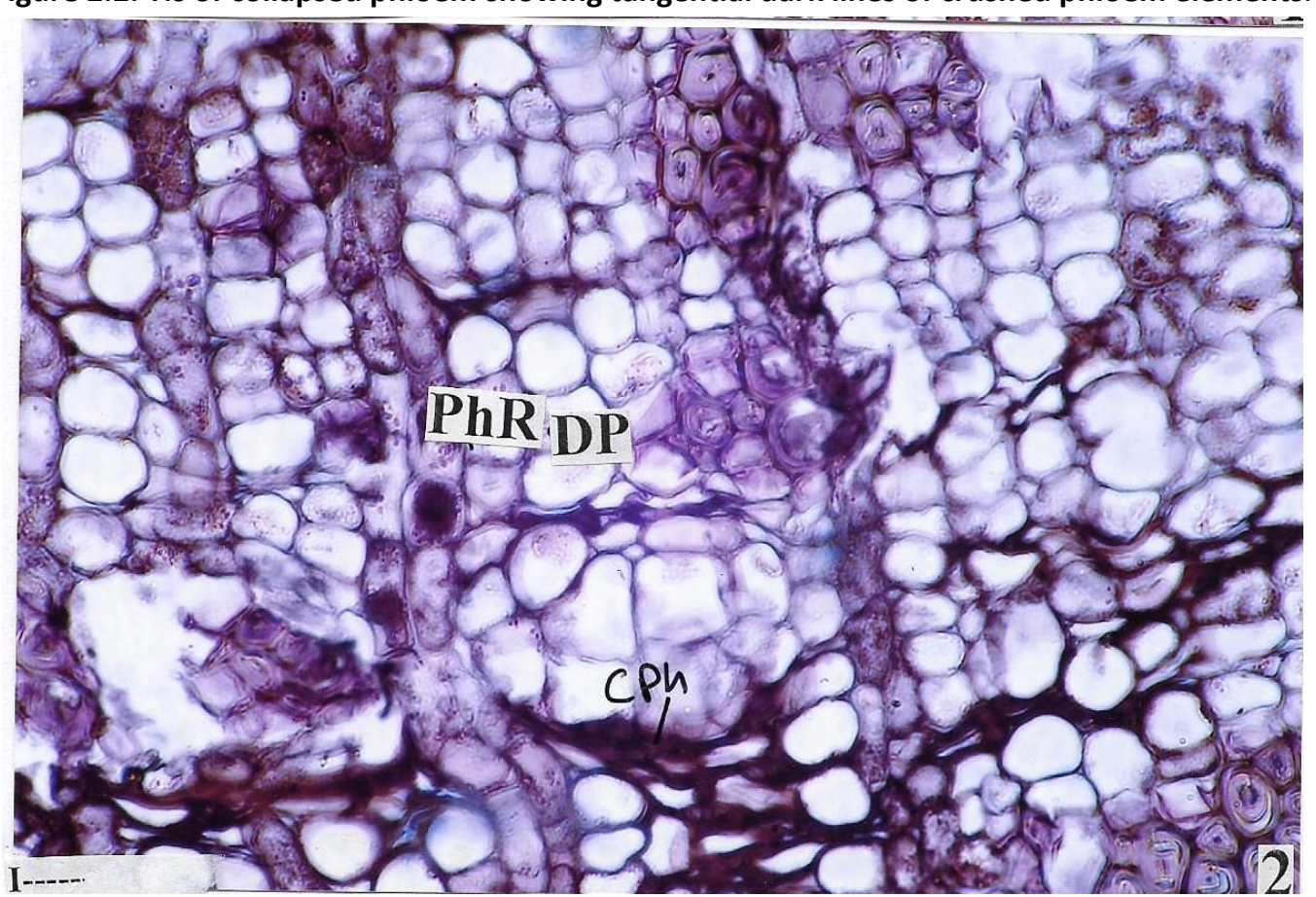

( PhR - phloem ray; Dp - dilated parenchyma; Cph - collapsed phloem)

( PhR - phloem ray; PhP - phloem parenchyma; CC -Companion cell; SE - Sieve elements PhF-phloem fibre)

Figure 3.2: Non- collapsed phloem elements enlarged 


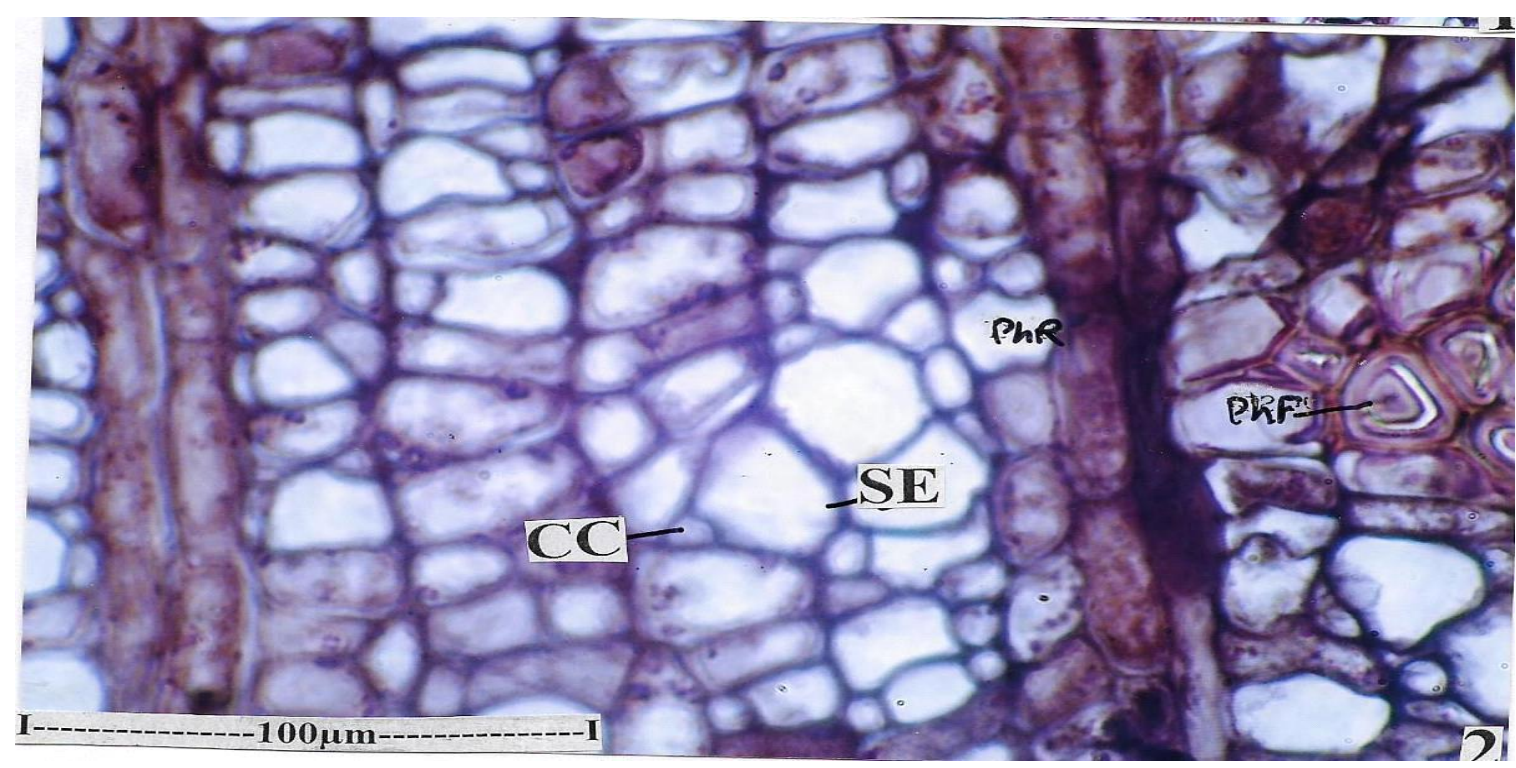

(PhR-phloem ray; PhF-phloem fibre; se- sieve elements; Cc-companion cell;)

Figure 4.1: T.L of phloem showing phloem rays

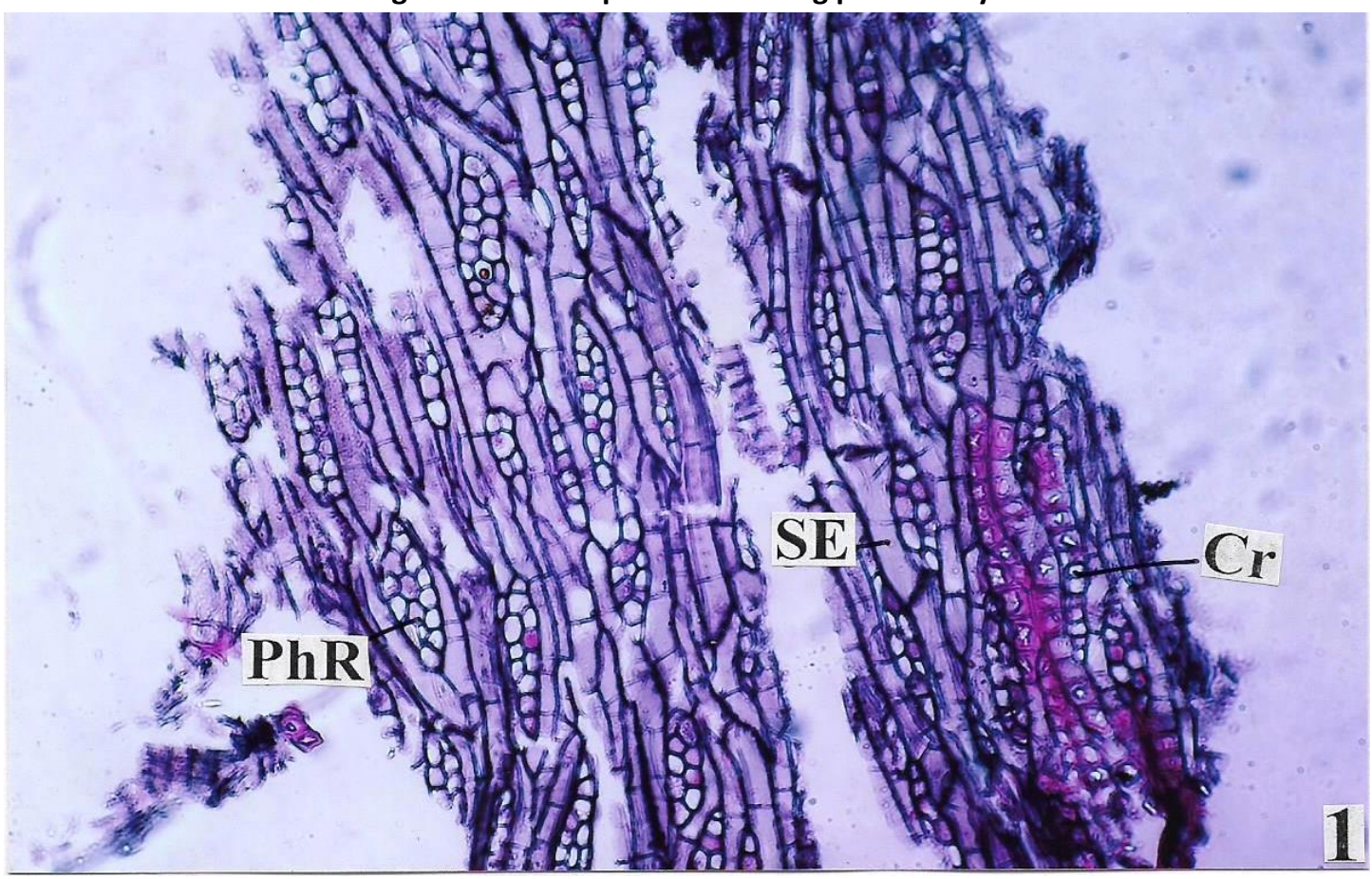

(Cr-crystal; Se-sieve elements; PhR-phloem ray) 
Figure 4.2: Phloem rays and sieve elements enlarged

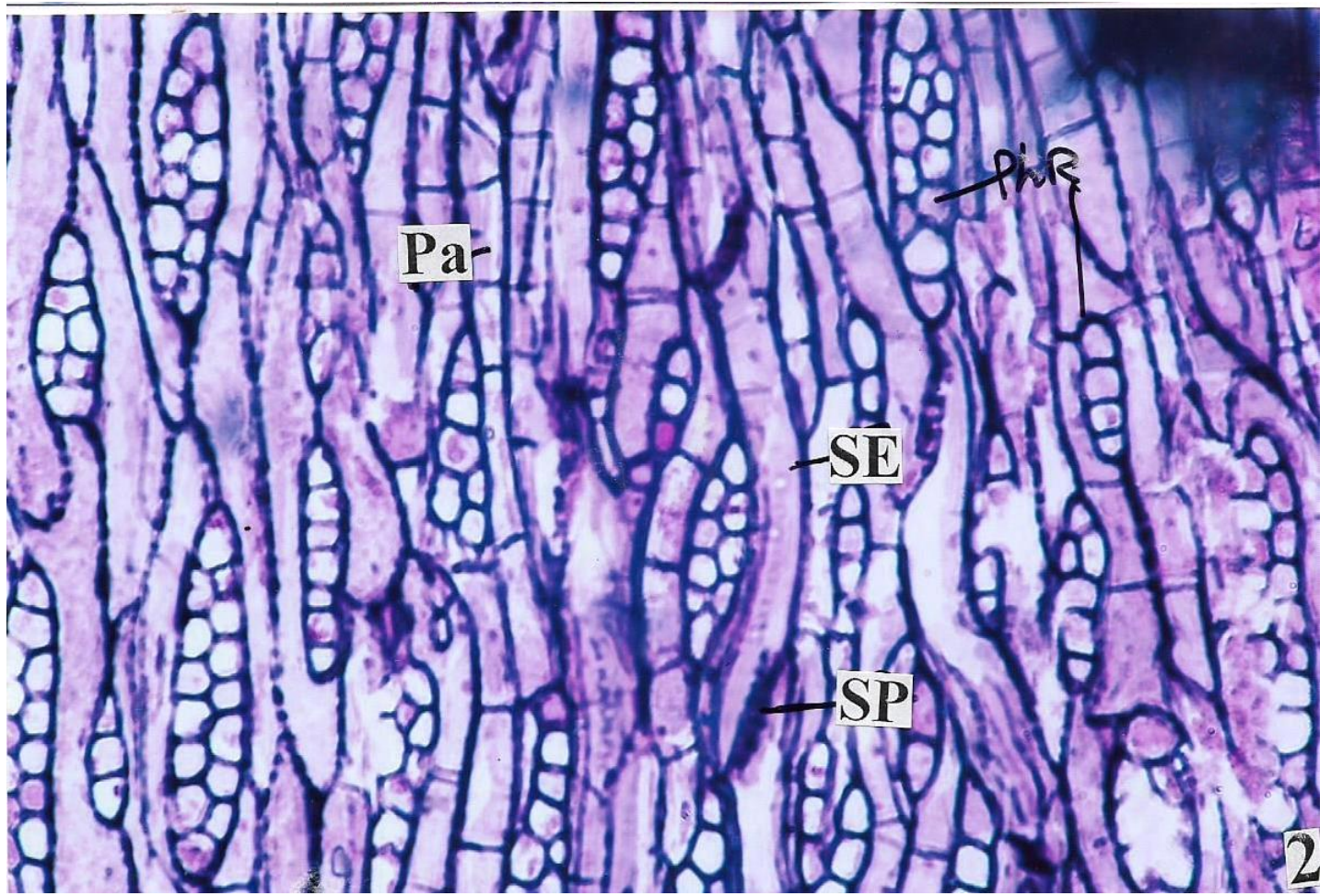

( pa-parenchyma; PhR-phloem ray; Se-sieve elements; Sp-sieve plate)

Figure 5.1: T.L of view of phloem showing ray seriation and ray arrangement

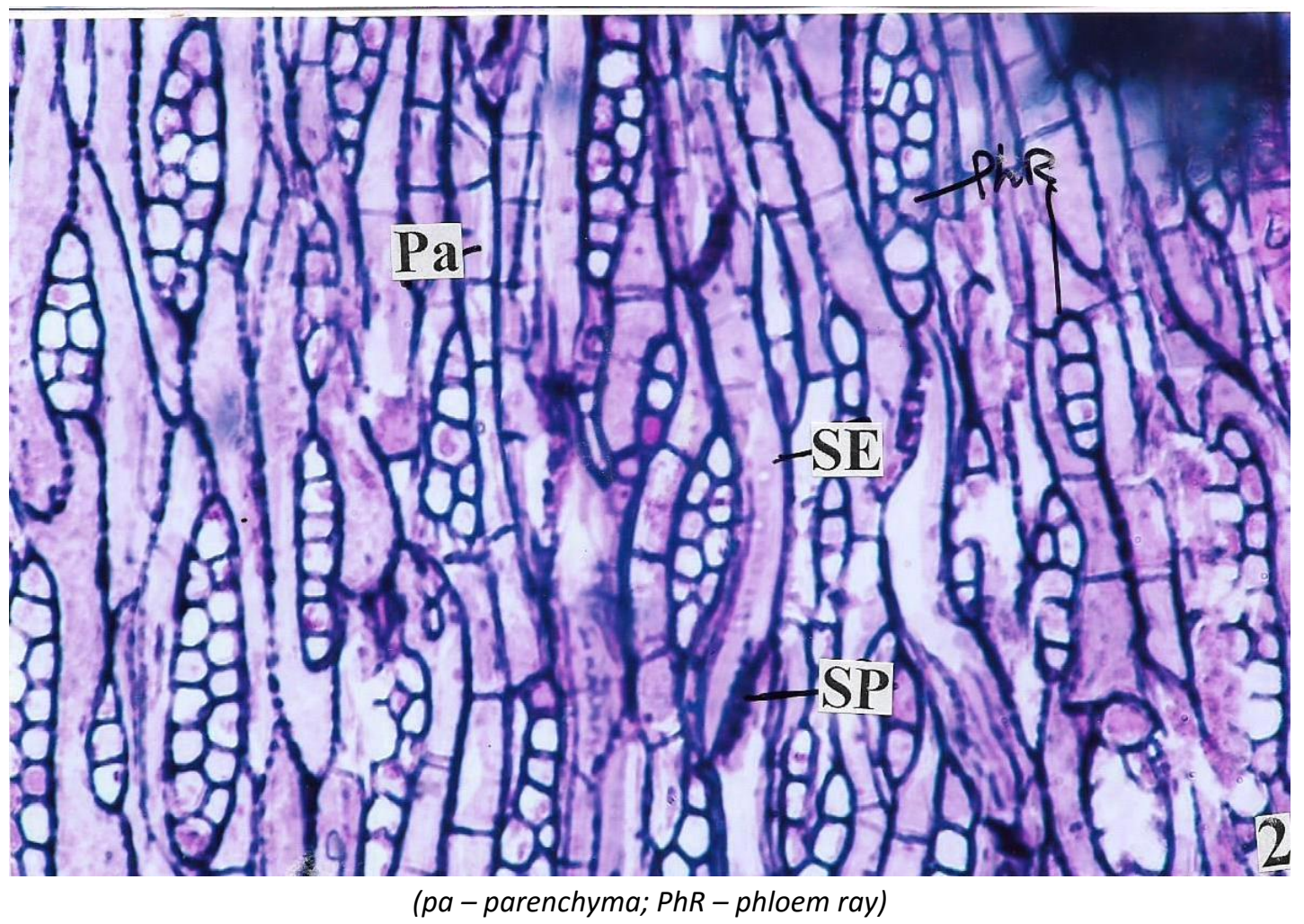


Figure 5.2: Phloem, uniseriate and biseriate rays.

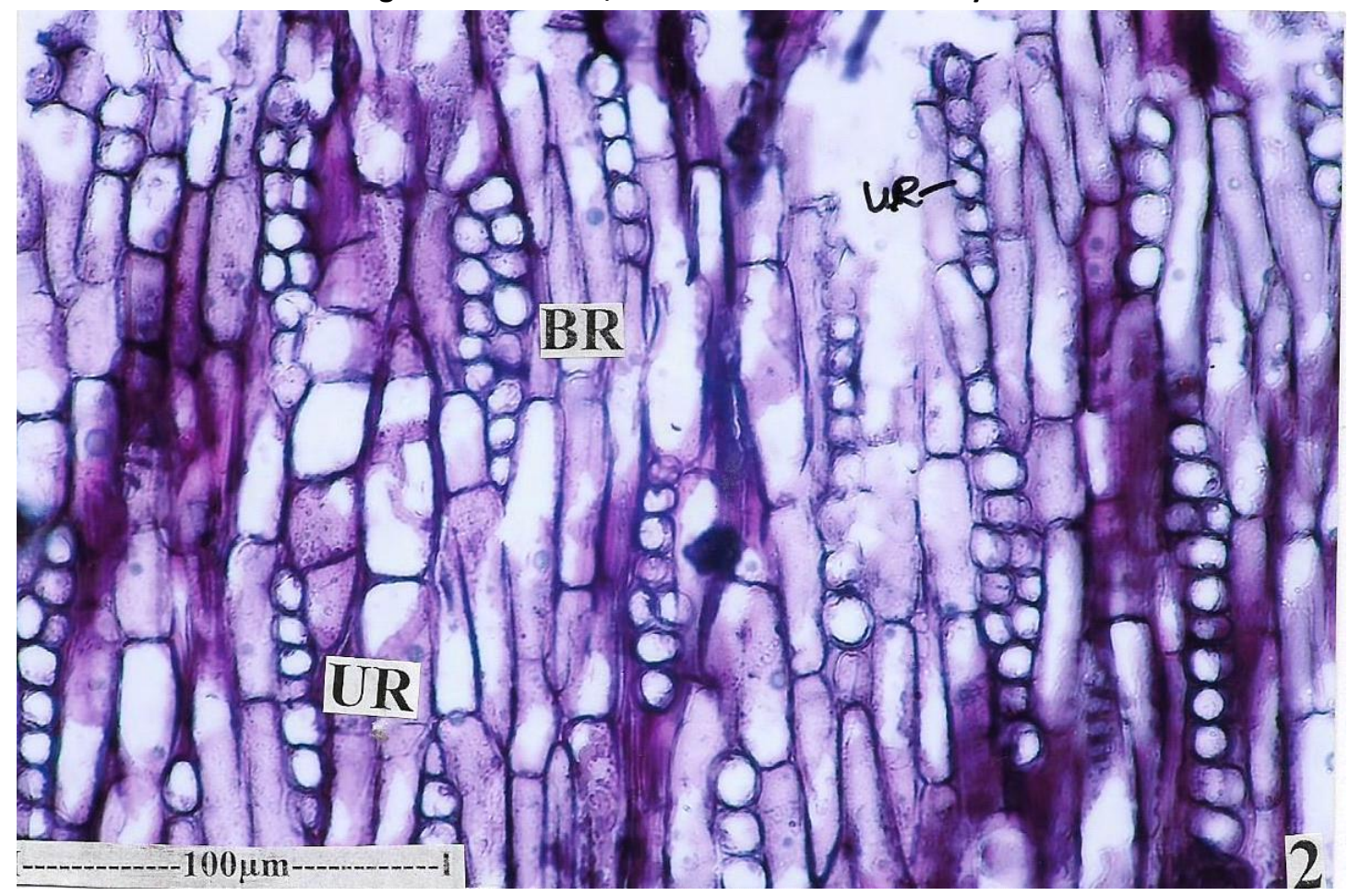

(Ur - Uniseriate; $B r$ - biseriate ray;)

Figure 6.1: Phloem showing biseriate rays, multiseriate rays and uniseriate rays.

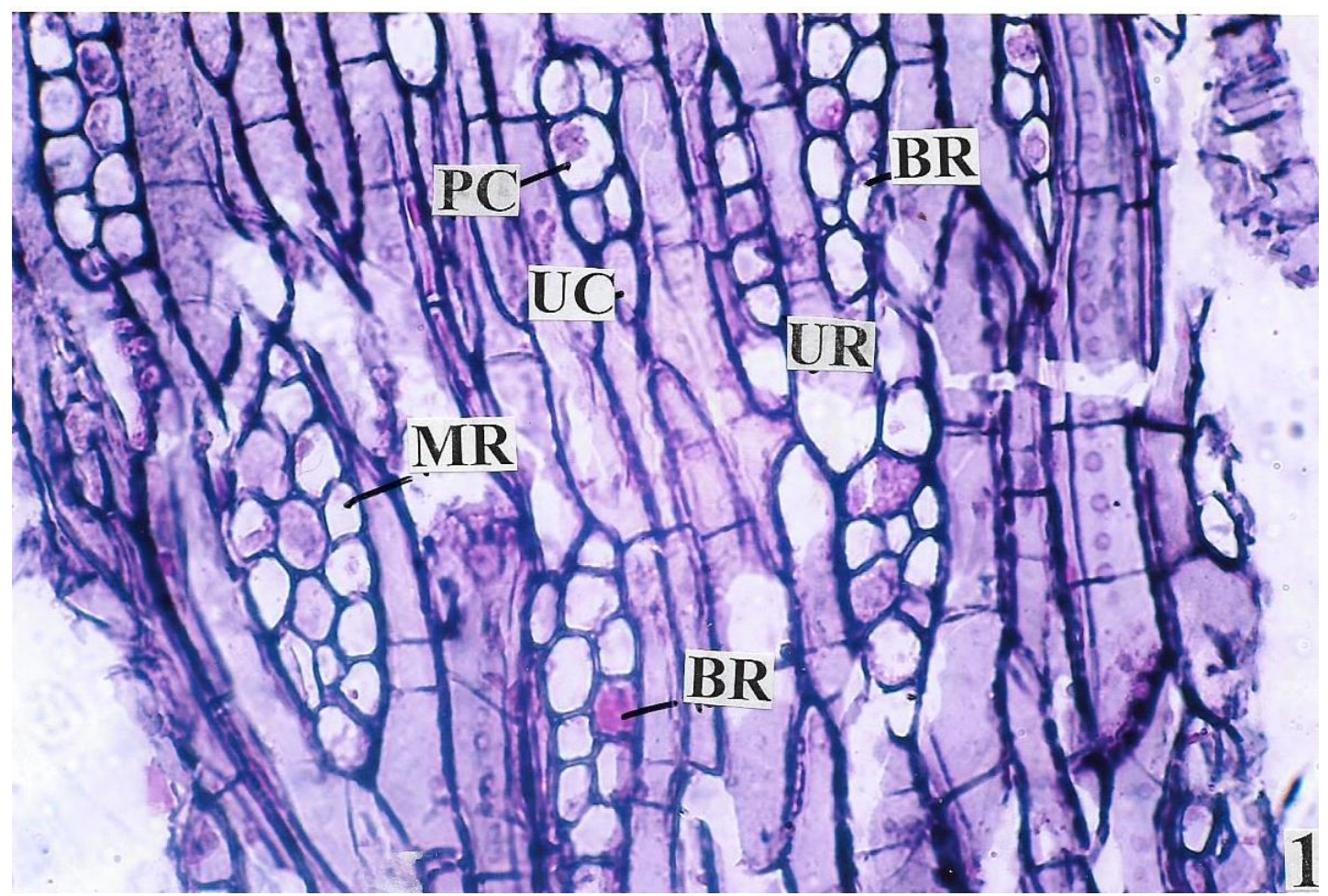

(Br-biseriate ray; $P c$ - procumbent; Uc-Uniseriate ray; Mr- multiseriate rays)

Figure 7.1: R.L.S of phloem showing horizontal oriented phloem rays. 


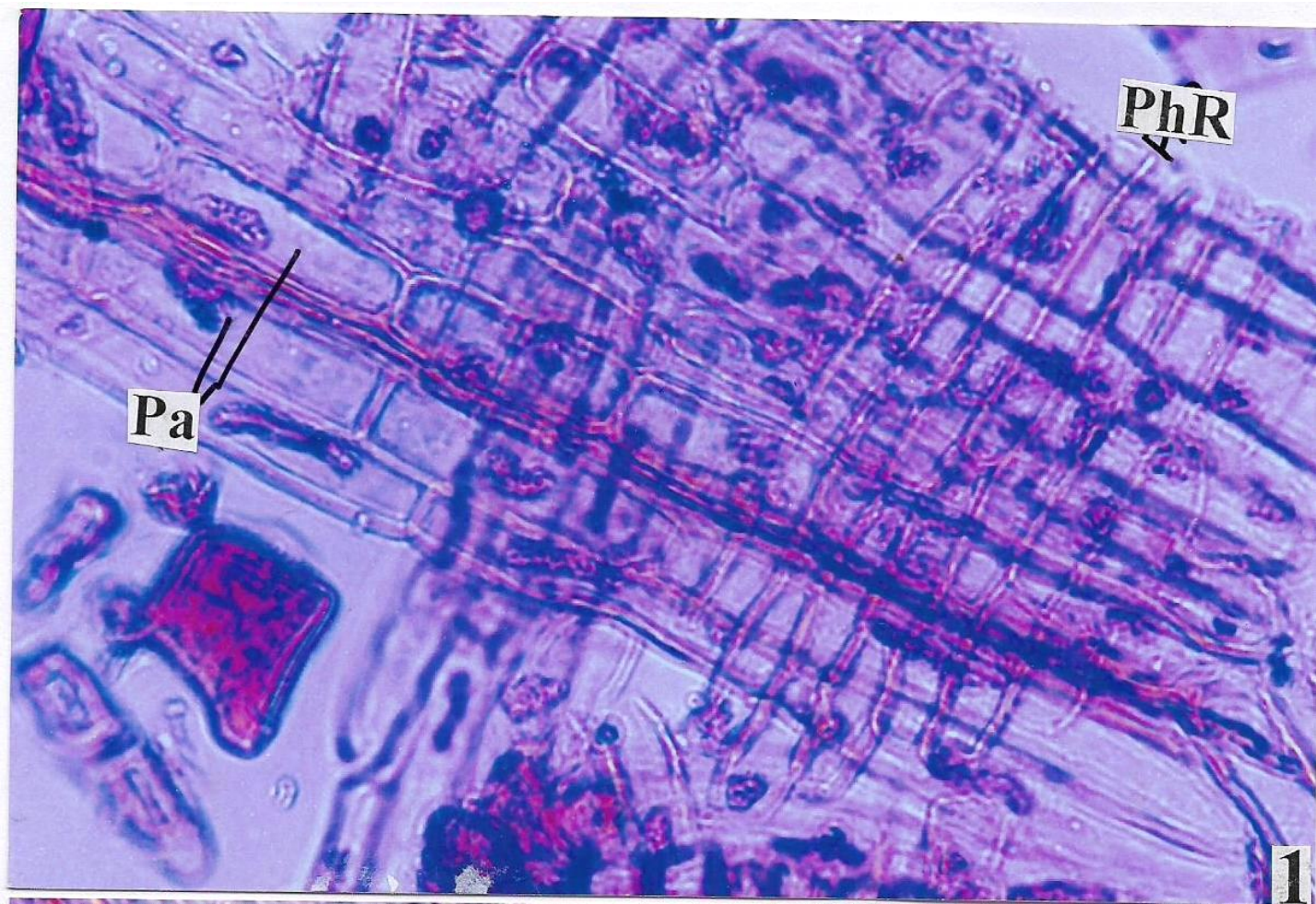

(Pa-parenchyma; PhR - phloem ray;)

Figure 8.1: Bark powder showing wide fibre and branch sclereids.

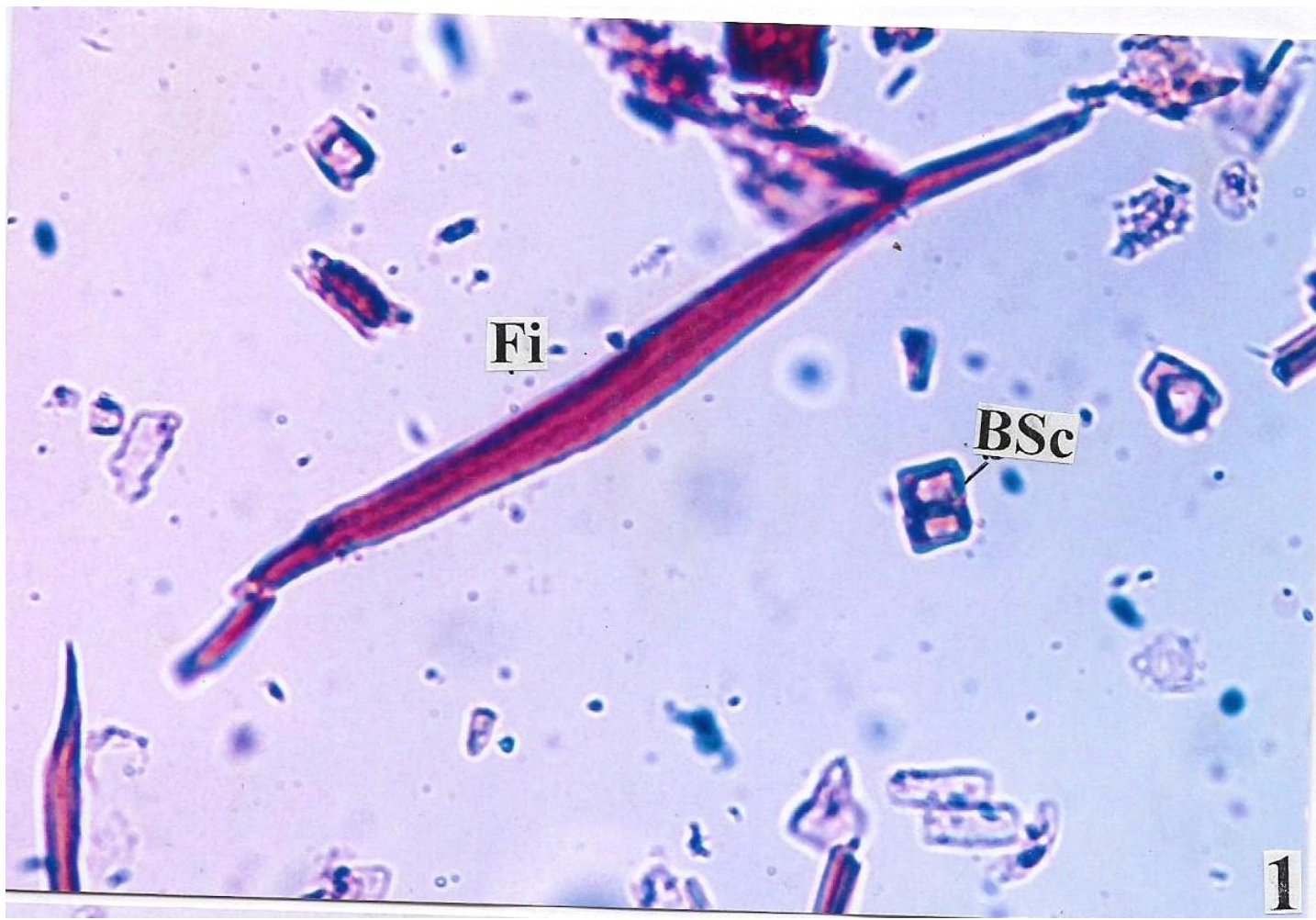

(Bsc- Brachy sclereids; fi- Fibres;) 
Figure 8.2: Long narrow fibre

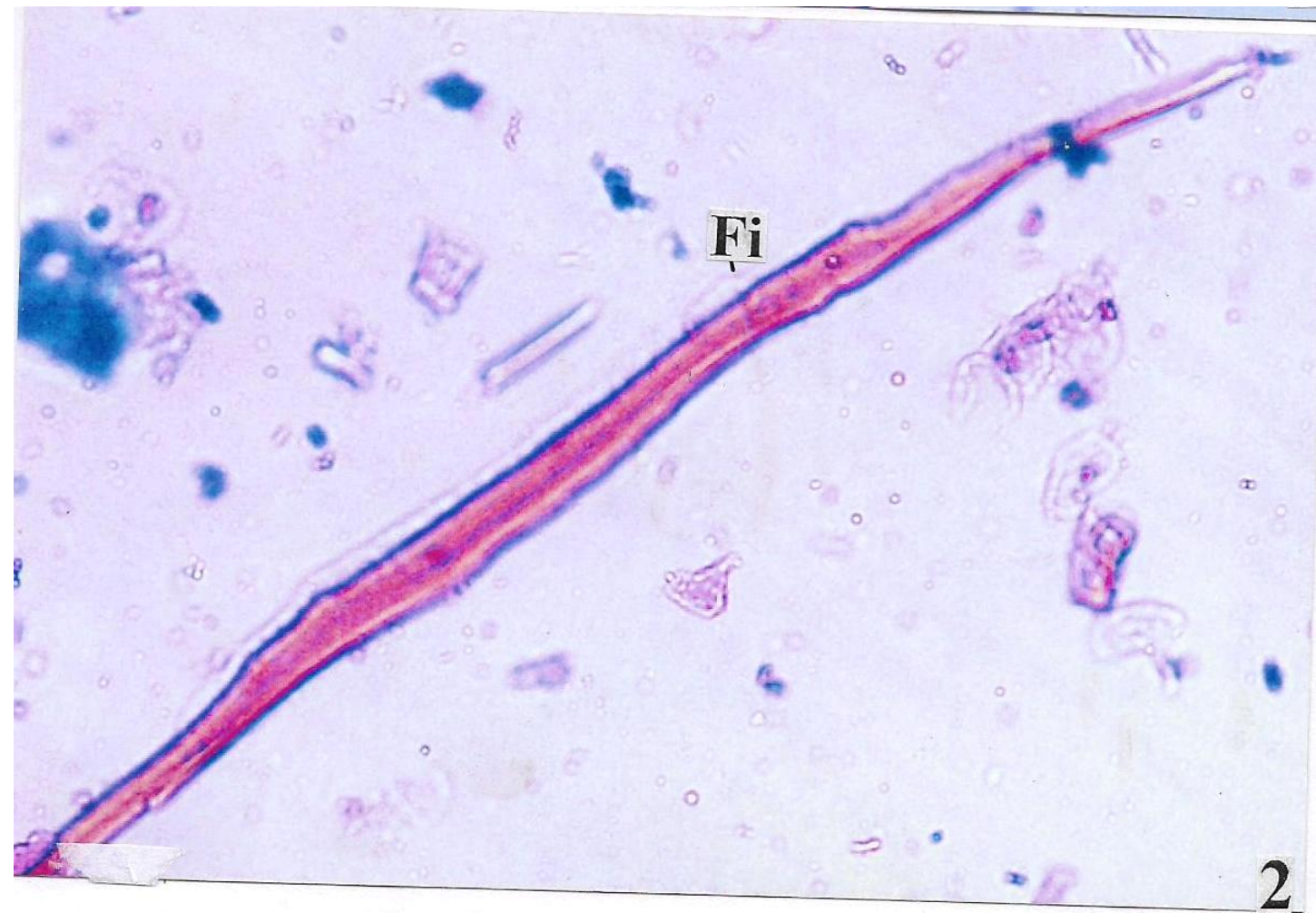

(Fi-Fibre;)

IX. ii) Powder microscopy of crude drug ${ }^{13}$ :

\section{S.NO NAME OF THE PARTS}

$1 \quad X Y L E M$

2 PHLOEM

3 VESSEL

\section{DESCRIPTION}

Xylem cells are long and narrow like pipes ROLE: They carry water

The main components of phloem are

Sieve element

Companion cells

ROLE: They conduct sugar and amino acid.

They are stacked one on top of another in long column.

ROLE: Water conducting tissue of plants.
IMAGE
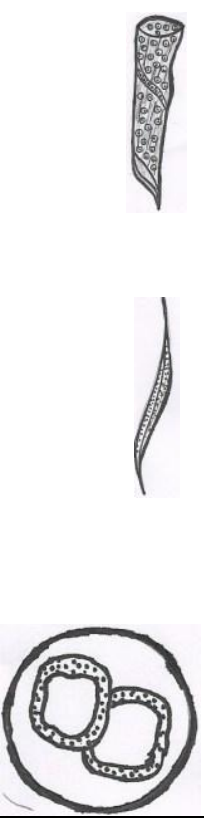


\begin{tabular}{|c|c|c|c|c|}
\hline \multirow[t]{2}{*}{4} & CORTEX & \multicolumn{3}{|c|}{$\begin{array}{l}\text { Cortex is the outer most layer thin walled } \\
\text { parenchyma cells in the ground tissues. }\end{array}$} \\
\hline & & \multicolumn{3}{|c|}{$\begin{array}{l}\text { ROLE: Food storage. } \\
\text { Mechanical support. }\end{array}$} \\
\hline 5 & \multirow{2}{*}{\multicolumn{2}{|c|}{ PERIDERM }} & \multicolumn{2}{|c|}{$\begin{array}{l}\text { Periderm is the soft growing tissue between bark ano } \\
\text { wood. }\end{array}$} \\
\hline & & & \multicolumn{2}{|c|}{$\begin{array}{l}\text { ROLE: Outer corky protective of the woody stem anc } \\
\text { roots. }\end{array}$} \\
\hline & & \multicolumn{3}{|c|}{ IX.iii) Results of physical evaluation: } \\
\hline & & S.No & Evaluation test & Values obtained in $\% \mathrm{w} / \mathrm{w}$ \\
\hline & & 1. & Moisture content & 0.973 \\
\hline & & 2. & Ash content & \\
\hline & & & Total ash & 9.03 \\
\hline & & & Acid insoluble ash & 1.6 \\
\hline & & & Water insoluble ash & 4.70 \\
\hline & & 3. & Extractive value & \\
\hline & & & Water soluble extractive & 4.66 \\
\hline & & & Alcohol soluble extractive & 10.039 \\
\hline & & & Ether soluble extractive & $101.55 \mathrm{mcg} / \mathrm{ml}$ \\
\hline
\end{tabular}

\section{CONCLUSION}

$>$ Cassia fistula linn belonging to family
caesalpiniaceae, popularly known as Indian laburnum is highly valued medicinal plant.

It is known as a rich source of tannins, triterpenes, flavanoids ${ }^{20}$ and glycosides present in cassia fistula, might be medically important and/or nationally valuable.

$>$ The plant undergone the standardisation procedure such as
I. Authentification
II. Physico chemical studies
III. Pharmacognostical studies.

A further study has to be performed for the characterisation, Isolation, Spectral studies of compounds. This gives the ideas about wide range of compounds in cassia fistula. Hence cassia fistula usage in medicinal field to treat various ailments.

\section{REFERENCES}

1. Sushma Kainsa, Praveen Kumar, Poonam Rani. Pharmacological Potentials of Cassia auriculata and Cassia Fistula Pants: Review. Pakistan Journals of Biological Science 2012; 15(9): 408-417

2. Gamble. J.S, et al. Flora of the Presidency of Madras Vol I, II, \& III. Botanical Survey of India, Calcutta, India.

3. Henry. A.N, et al. Flora of TamilNadu, India- Vol.3. Botanical Survey of India, Southern Circle, Coimbatore, India. pp-258:1987.

4. Mathew K.M, et al. The Flora of Tamil Nadu Karnatic. Vol. Polypetalae, Vol.3. Gamopetalae \& Monochlamydae. The Ranipat Herbarium, St. John's College, Tiruchirappalli, India. Pp. 688, pp689-1540.

5. Metcalfe C.R, et al. Anatomy of the Dicotyledons- Vol. I \& II. Clarendon Press, Oxford. 1950.

6. Aurapa sakulpanich, et al. Determination of anthraquinone glycoside content in cassia fistula leaf extract for alternative source of laxative drug; international journal of biomedical and pharmaceutical sciences, 3(1); 42-45. 
7. Aurapa sakulpanich, et al. extraction method for high content of anthraquinone from cassia fistula pods. J health res, 2008; 22(4):167-172.

8. Markout $M$, Bekkouche K, Larhsini M. Bousaid M. Lazrek HB, Jana $M$, Evaluation of some Moroccan medicinal plant extracts for larvicidal activity.J. Ethanopharmacol,2000;73:293-297.

9. Alam. MM, et al. Treatment of diabetes through herbal drugs in rural India.

10. Patel $D$, et al. Antipyretic and analgesic Activities of Aconitum spicatum and Cassia fistula. Pharm. Biol. 1965; 157: 2227.
11. Satyavati GV, et al. Medicinal plant in India: ICMR: New Delhi, India, 1989.

12. Kokate.C.K. Evaluation of crude drug. (ed). Practical Pharmacognosy, 5th ed.: M.K.Jain; 2014. pp. 125-127.

13. O. Brien, et al. Polychromatic Staining of Plant Cell Walls by toluidine blue- $O$, Protoplasma:59:364373:1964.

14. Kokate. C.K. Analytical Pharmacognosy. (ed). Pharmacognosy, 33rd ed.: Nirali Prakashan; Nov: 2005. pp. 97-132.

15. http:||www.deserttropicals.com/plant/Fabacae/cassi a_fistula a.html
*Corresponding Author:

B Lavanya*

Email:blavanyavels@gmail.com 